\title{
Margaret McCartney: The NHS can't afford more litigation
}

\author{
Margaret McCartney general practitioner
}

Glasgow

Things go wrong in the NHS every day. Complaints to the General Medical Council by the public rose from 3858 in 2010 to 5808 in 2014 . $^{1}$ The NHS Litigation Authority has, compared with last year, nearly doubled the money it sets aside for future claims to $£ 56.4 \mathrm{bn}$ ( $€ 65.9 \mathrm{bn}$; $\$ 73.6 \mathrm{bn}$ ), having paid out $£ 1.4 \mathrm{bn}$ in the past year. ${ }^{2}$ (The NHS annual budget is $£ 116 \mathrm{bn} .{ }^{3}$ )

Doctors are encouraged to be honest about errors that cause harm: this ethical position predated duty of candour, which legally requires doctors to do this (it's likely to become law in Scotland, too). To prevent avoidable mistakes we must be able to talk about them and mitigate them systemically. Rare is the mistake that's made by only one person. We keep hearing about the importance of transparency, openness, and "a learning culture, not a blame culture."

Now look at the many law firms offering "no win, no fee" representation for purported medical errors, and ask yourself what this means for patient care. One such website advertising to patients, from the law firm Bolt Burdon Kemp, contains advice so detailed about what doctors should and shouldn't do that it reads more like NHS Direct. ${ }^{4}$ Another website finds both overtreatment and undertreatment ripe for legal claims. ${ }^{5}$ Another says that, if a GP doesn't make a correct initial diagnosis, the impact may be devastating and worthy of compensation. ${ }^{6}$

Significant event analysis, intended to identify and reduce future risk, is now requested by lawyers to be used against doctors

We have a serious mismatch of agendas, and it's unsustainable. Many of the stories I hear about things that go horribly wrong in the NHS are compounded by organisations that have become defensive and obstructive and have shut down rational communication. Seen through another lens, such organisations may be attempting to stop litigation against themselves. We're now in an era where significant event analysis, intended to identify and reduce future risk, has been requested by lawyers to be used against doctors. ${ }^{7}$ Some complainants find peace in litigation, but it's slow, it's expensive, and it allows systemic errors to keep happening while it rumbles on. This is bad for us all.

It's time we looked to ethics rather than to blame and compensation. Indemnity cover is rising, ${ }^{8}$ and the fear of being sued and blamed worries many doctors. ${ }^{9}$

Citizens should be asked: is this how you want to proceed-spending ever more money on litigation, which will mean less for patient care? Or would you like a new covenant: rapid investigation and dissemination of outcomes from complaints; safe staffing; adequate resourcing; and a truly fair culture aimed at limiting the wish to make compensation claims at all? Surely there are other ways to make healthcare safer, and payouts fairer, than litigation in its current form.

For doctors, the alternative is to cover your back and refuse to work unsafely. I reckon that this would mean most GPs seeing only half their current number of patients and would lead to more inappropriate referrals. Is that what the public wants?

Competing interests: See www.bmj.com/about-bmj/freelancecontributors/margaret-mccartney.

Provenance and peer review: Commissioned; not externally peer reviewed.

Follow Margaret on Twitter, @mgtmccartney

1 General Medical Council. The state of medical education and practice in the UK. 2015 www.gmc-uk.org/SOMEP 2015.pdf 63501874.pdf.

2 NHS Litigation Authority. Annual report and accounts 2015/16: resolve and learn. Jul 2016. www.nhsla.com/AboutUs/Documents/NHS_Litigation_Authority_Annual_Report_ and_Accounts_2015-2016.pdf.

3 King's Fund. The NHS budget and how it has changed. 15 Jan 2016. www.kingsfund.org. uk/projects/nhs-in-a-nutshell/nhs-budget.

4 Bolt Burdon Kemp. Ovarian cancer misdiagnosis claims. www.boltburdonkemp.co.uk/ medical-negligence/cancer-misdiagnosis/ovarian/.

5 Leigh Day. Concerns over work of retired consultant with Royal Cornwall Hospitals NHS Trust. 14 Nov 2012. https://www.leighday.co.uk/News/2012/November-2012/Concernsover-work-of-retired-consultant-with-Roya.

6 Patient Claim Line. GP claims. www.patientclaimline.com/claim-types/gp-claims/.

7 Furmedge D. Written reflection is dead in the water. BMJ Careers 2016 Jun 20. http:// careers.bmj.com/careers/advice/Written reflection is dead in the water.

8 Rimmer A. GP indemnity fees rise by $25 \%$ in a year, survey finds. BMJ Careers 2015 Sep 3. http://careers.bmj.com/careers/advice/GP_indemnity_fees_rise_by_25\%2525_in a_year,_survey_finds. 
9 McGivern G, Fischer M. Medical regulation, spectacular transparency and the blame business. J Health Organ Manag 2010;24:597-610. doi:10.1108/14777261011088683 pmid: 21155435.
Published by the BMJ Publishing Group Limited. For permission to use (where not already granted under a licence) please go to http://group.bmj.com/group/rights-licensing/ permissions 